\title{
Learning together assisted with of 7-in-1 box: Creating Effectiveness of Mathematic Learning outcomes of Elementary School
}

\author{
Eka IRAWATI ${ }^{1}$, Ali MUSTADI ${ }^{2}$
}

\begin{tabular}{l} 
ARTICLE INFO \\
\hline Article History: \\
Received 01.11.2018 \\
Received in revised form \\
08.02 .2019 \\
Accepted \\
Available online 01.07 .2019
\end{tabular}

\begin{abstract}
The implementation of learning model along with the manipulative tools is a key of achievement of mathematic learning. The combination of learning together model and manipulative to ol of 7 in 1 boxis one of options for teacher in teaching mathematic in elementary school, because it has great effect of learning outcomes. This study aims to find out the effectiveness of learning together model assisted with 7 in 1 box toward the result of mathematic learning on 4rth grade students of SDN Gugus Bisma. This is a quasi experimental study using nonequivalent pretest-posttest control group design. The population of 4 th grade students of SDN Gugus Bisma was 135. Meanwhile, the sampling was conducted by using cluster sampling and it was obtained that 4 th grade students of SDN 1 Sokawera as many as 30 students as experiment class and 4 th grade of SDN 3 Sokawera as 25 students as control class. Data analy sis by using $\mathrm{z}$-test, gain and $\mathrm{N}$-gain test, $\mathrm{t}$-test. From the result of $z$-test it was obtained that $z$-table $=1,64$, on experiment class $(z$-score $=3,16)$ and control $(z$-score $=$ 2.89 ). the result of analy sis of $g$ ain test shows that the gain value of experiment class $=22$ and control class $=15$, meanwhile $\mathrm{N}$-gain test shows that $\mathrm{N}$-g ain of experiment class $=0.58$ and control class $=0.40$. both class show the increase of learning outcome of medium categ ory. From T-test it was obtaine tscore (4.41) > t-table (1.705), thus Ho was rejected. The conclusion shows that the implementation of learning together assisted with 7 in 1 box effective in increasing the study result of mathematic on 4 th grade students of SDN Gugus Bisma.
\end{abstract}

Keywords: ${ }^{1}$

CIJERE. All rights reserved

Learning Together, Mathematic in Elementary School, 7-in-1 box.

\section{INTRODUCTION}

Entering $21^{\text {st }}$ century, education become one way to direct every individuals to achieve High Order Thingking Skill (HOTS). Mathematic is a part of education which can facilitate in developing HOTS. Mathematic is given since in elementary school, with the purpose to train students to have analytical thinking ability, creativity, critical thinking, logic, systematic and it train the ability to have work in a team. The implementation of learning process in Indonesia based on education minister decree number 22 year 2006 about standard content, explain that in every time of mathematic learning is started with problem identification according to situation (contextual problem). This is strenghten by (Warner \& Kaur, 2017) which states that when teacher conduct learning process they must relate mathematical material with realworld problems, so students can be more challenged in solving problems and making them more concer ned with social problems and creative. By recofnizing real problems carried out in everyday life, the students involved understand mathematical concepts. In addition, according to (Amin \& Suardiman, 2016) it needs a cooperative learning model in mathematics learning so that it can help students be more active in the learning process, then according to (Kristiani \& Prasetyo, 2016) in mathematics learning needs using concrete media in order to attract students' attention. The second propose also shows that implementing cooperative learning models and using concrete media in mathematics learning can improve student learning achievement effectively. Through real problem identification, students are gradually directed to know and understand mathematic concept reated to daily problem and encourage students to actively involves in learning process.

But in reality there are still many problems encountered in the process of implementing mathematics learning. As explained by (Muchyidin \& Kartika, 2014), that in mathematics learning students often regard mathematics as the most difficult lesson to understand. Based on the results of observations carried out in Mathematics learning at SDN Gugus Bisma Somagede Banyumas, it was shown that mathematics learning carried out by teachers had led to cooperative learning Student Facilitator And Explaining (SFaE) type. SFaE is similar to peer tutoring learning, but SFaE has one of its own characteristics in the implementation of

Corresponding e-mail: ekairawati.2017@student.uny.ac.id ${ }^{1}$; ali_mustadi@uny.ac.id 2

Orcid Kode: orcid.org/0000-0003-1436-6719 1; orcid.org/0000-0002-7620-4582 2

Student Magister of Pendidikan Dasar, Univertitas Negery Yogyakarta 1; Lecture of Pendidikan Dasar, Univertitas Negery Yogyakarta 2 
learning, namely placing students in a group consisting of 5-6 students, then one student who masters the material has the task to repeat the delivery of material that has been explained by the teacher to his friends. Even though the learning is considered to be directed tow ards student learning center, in reality only some students are active in learning activities, so that there is a gap betw een students who are able to master the material and students who have not been able to master the material. Students who are able to master the material become increasingly active, while students who have not been able to master the material tend to ignore the delivery of material delivered by their friends.

In addition, there are several other problems that arise in learning process of mathematics in all SDN Gugus Bisma Somagede Banyumas, in which there was a dominance of the introduction of verbal formulas and concepts in learning, so that learning has not been able to foster a creative, interactive, inspirational, enjoyable learning atmosphere, challenging, and unable to motivate students to actively participate in group activities. Some of the problems occur have an impact on student learning outcomes. The mathematics learning outcomes of most students showed that they were still below the Minimum Completion Criteria (KKM) that had been set. Referring to the mathematics learning problems, it is necessary to change the learning of mathematics in elementary school, that is from mechanical learning into humanistic learning and emphasize the active and independent learning of each student. The aimed change is to implement a learning model that can direct all students to be actively involved in mathematics learning activities. Learning will be more meaningful and structured when we implement a learning model. According to (Mulyanto \& Indriayu, 2018) stated that the mathematics learning outcomes of students in the class that apply the learning model get higher scores compared to classes that do not apply the learning model (conventional class). According to (Joyce, 2015) the learning model is a plan, which can be used to determine a curriculum, to select teaching materials, and to provide guidance on activities carried out by the teacher. The statement shows that the learning model can create more directed learning and can be a guideline for teachers and learning designers when designing and implementing learning activities. There are various kinds of learning models that can be used in mathematics learning. According to (Rahmawati \& Mahmudi, 2014) learning models that are effectively used in mathematics learning are cooperative learning models, by applying cooperative learning models, then student activities and learning achievements can increase optimally. (Meganingtyas, Winarni, \& Murw aningsih, 2019) also argued that the application of cooperative learning models in learning can be a solution to create a fun learning process and involve students to actively participate in the learning process, so that students can understand the material delivered by teacher. There are various kinds of cooperative learning models that can be used in mathematics learning. In this study researchers were interested in the Learning Together (LT) type cooperative learning model.

The LT was first proposed by David Johnson and Robert Johnson. At that time, in 1975 David Johnson and Robert Johnson published a book entitled Learning Together and Along: Cooperation, Competition and Individualization, after the book was published LT became one of the most well-known cooperative learning (Huda, 2015:119). LT can be considered as a model because it has a learning syntax that can provide clues to the activities carried out by the teacher. Fathurrohman (2015:68-69) states that there are 5 steps that must be taken in implementing LT, those are (1) Submission of subject matter conducted by the teacher, (2) Formation of small groups consisting of 4-5 students selected heterogeneously (mix according to achievement, gender, ethnicity, etc.), (3) Distribution of assignment sheets to each group as material for discussion and completion, (4) Presentation of group discussion results, (5) Giving praise and appreciation. LT is one part of cooperative learning that can improve students' academic abilities. Accord ing to (Ozsoy \& Yildiz, 2004) showed that cooperative learning can be a strong basis for learning mathematics, because when students learn mathematical logic, students need to be directed to share their opinions with others, and use mathematics to solve problems. Then according to the Department for Education and Child Development (2013) states that learning activities carried out together (Learning Together) can provide changes in ability to children, which includes increasing knowledge, skills, and confidence in children. This statement is strengthened by (Gürbüz, 2013), showing that learning from LT can improve student learning achievement. Based on these three statements, it shows that LT can be used in the learning process of mathematics, with the aim that students can interact with each other, share information with their friends about the various knowledge they have to solve problems related to mathematics, and can help improve the ability of attitude, knowledge, and student skills. 
LT provides opportunities for students to discuss. (Johnson \& Johnson, 2006) in LT, the teacher prepares cooperative learning, based on the use of learning based on experience and the use of small groups in problem finding and problem solving activities. So that it can be interpreted that in the LT learning activities each group gets a worksheet as material for discussion, then each group must work together and be responsible for completing the task. These activities require each student to actively participate in expressing various ideas or ideas to complete the task given. The selection of the LT is also based on three things, those are (1) LT can be used to teach specific content, (2) LT can help cognitive processing actively during learning activities, and (3) LT can provide long-term support and can help academic progress can be used in every curriculum and all students of various ages (Johnson \& Johnson, 2006). In addition, according to (Ghaith, 2003) LT provides a conceptual framew ork for teachers to plan and adapt cooperative learning instructions according to their circumstances, student needs, and school context. Both of these statements can be the basis that when the LT is applied in learning mathematics it can help develop students' thinking abilities, because the teacher can plan learning according to the needs and conditions of the student's learning environment. The advantages of LT when applied in learning include, (1) through discussion activities can increase the level of student activity in learning, (2) increase student collaboration in groups with the principle of shared learning, (3) through presentation activities will train students to be brave and confident, (4) leads to student center learning because the teacher acts more as a facilitator while students are given the opportunity to explore their own knowledge, and (5) make students more creative (Rahayu, et al., 2015). These advantages can be an expected result when the teacher applies the LT in mathematics learning.

Besides implementing the learning model, learning mathematics in elementary school requires the manipulation of concrete objects. Through activities to manipulate concrete objects can help students to facilitate understanding the material. It is also supported by research results (Cope, 2015) which states that using manipulative objects students can develop an understanding of new concepts and interact with the environment authentically. "7 in 1 Box " is one of the concrete objects that can be used in mathematics learning and is a modification of the geoboard created by Chandrawati. 7 in 1 Box according to (Chandraw ati, 2013) can demonstrate 7 mathematics learning materials, namely reflection, rotation, cartesian coordinate system, determine the circumference and area of rectangles and squares, recognize simple flat builds, integer counting operations and play chess. As a result of new innovations from geoboard, the 7 in 1 box can also help concretize abstract mathematical material. In line with these statements, research (Scandrett, 2008) shows that geoboard can support learning about measurement, space and geometry. Through geoboard understanding of geometry students can also develop (Furner \& Marinas, 2011: 113). The results of the study (Salahudeen \& Saidu, 2016) also mentioned that Geoboard can improve student performance in learning.

Based on the explanation above, the researcher combines the application of a 7 in 1 box learning model in mathematics learning. The researcher assumes that LT assisted the 7 in 1 box can realize $21^{\text {st }}$ century learning, namely learning that refers to student learning centers, so students have high cognitive thinking abilities.

\section{Situation of the Problem}

The problems of mathematics learning in elementary are not ongoing inspirational, interactive, creative, challenging, fun and motivating learning to actively participate in learning activities, besides that from the teacher also has not implemented a learning model that can build creativity and independence students in mathematics learning. So that overall mathematics subjects are still a frightening specter for students in elementary school.

\section{Aim of the Study}

The aim of this study was to determine the effectiveness of the LT model assisted with 7 in 1 boxes in mathematics learning if viewed from the learning outcomes of fourth grade students of SDN Gugus Bisma. 


\section{METHOD}

This research is a experimental research type, using a quasi-experimental design. Johnson \& Christensen (2014: 485-486) mention that quasi-experimental design is an experimental research design which does not provide full control of potential confounding variables. This shows that in the implementation there is no randomization of students into the new class, so that in this study carried out by utilizing existing student classes.

The form of the quasi experimental design used in this study is The Nonequivalent Prettest-Postest Control Group Design. By using this design, there are experimental and control classes, which both get the pretest and posttest with the aim of knowing the students' initial abilities and final abilities between before and after getting treatment.

\section{Material}

The population in this study was fourth grade students from 6 elementary schools in Bisma Cluster Somagede sub-district, Banyumas district, totaling 135 students and consisted of male and female students with an average age of 10 years. After determining the study population based on the existence of mathematical learning problems that resulted in student learning outcomes not maximal yet, researchers then determined the study sample. Determination of the study sample was conducted using a cluster sampling technique based on the reason that the population was normally distributed and homogeneous, so that the samples obtained were class IV SDN 1 Sokawera as many as 30 students as the experimental class and SDN 3 Sokaw era as many as 25 control classes. Each class uses manipulative objects in the form of a 7 in 1 box and gets 6 treatments, for the experimental class to get treatment by applying LT, while the control class gets treatment by applying SFaE to mathematics learning material of symmetry folding and mirror reflection.

The independent variables in this study were the LT learning model and the SFaE learning model. The dependent variable is mathematics learning outcomes in terms of cognitive aspects of class IV students. While for the control variable is the 7 in 1 box.

The instrument used in this study is a test instrument. The test instruments in this study were in the form of multiple choice questions as many as 40 items that had been tested for validity, reliability, differentiation, and degree of difficulty.

Data collection was obtained through pretest and posttest. The collected data is first tested for normality and homogeneity. After that, the descriptive analysis and hypothesis testing are then carried out. The statistical techniques used in descriptive analysis include the mean, variance, and standard deviation, with the aim of describing the data that has been obtained with clearer and more detailed words. Furthermore, there are three statistical tests that are used to test the research hypothesis. First, the test of the proportion of one party is used to test the learning completeness hypothesis. Second, the test of data gain and N-gain, is used to test the hypothesis of increasing the pretest and posttest learning outcomes. Third, the independent sample t-test two samples are used to test the hypothesis of learning effectiveness.

The independent study models and the SFaE learning model are the independent variables. The dependent variable is mathematics learning outcomes of cognitive aspects of class IV students. While for the control variable is the 7 in 1 box. The instrument used in this study is a test instrument. 40 items that have been tested for validity, reliability, differentiation, and degree of difficulty. Collection data was obtained through pretest and posttest.

\section{Data Analyses}

The collected data is first tested for normality and homogeneity. After that, the descriptive analysis and hypothesis testing are then carried out. Used in descriptive analysis, including the mean, variance, and standard deviation. Furthermore, there are three statistical tests that are used to test the research hypothesis. First, the test was used to test the learning completeness hypothesis. Second, the test of data gain and Ngain, is used to test the hypothesis of increasing the pretest and posttest learning outcomes. Third, the independent sample t-test is used to test the hypothesis of learning effectiveness. 
Irawati,E. \& Mustadi,A. (2019). Learning together assisted with of 7-in-1 box: Creating effectiveness of mathematic learning outcomes of elementary school. International Journal of Educational Research Review,4 (3), 310-319.

\section{FINDINGS}

The first research data collection was carried out by doing a pretest. The following are data on the pretest of grade IV students in the experimental class and the control class,

Table 1. Pretest of Experiment Class (KE) and Control Class (KK)

\begin{tabular}{llcc}
\hline No. & \multicolumn{1}{c}{ Description } & Experiment class & Control class \\
\hline 1. & Number of samples & 30 & 25 \\
2. & Minimum score & 40 & 50 \\
3. & Maximum score & 75 & 75 \\
4. & Average & 61 & 64 \\
5. & Complete & 11 & 9 \\
6. & Not complete & 19 & 16 \\
\hline
\end{tabular}

the data is used to determine students' initial abilities before getting treatment.

Then the normality test was carried out on pretest data using the lilliefors test, with the aim to find out the distribution of data from the pretest results of fourth grade students. The data from the experimental and control pretest classes are shown in the following table,

Table 2. Results of Pretest Normality of Experimental Class and Control Class

\begin{tabular}{llccccc}
\hline No. & Class & $\mathrm{n}$ & Lo & Lt (real level 5\%) & Interpretation & Note \\
\hline 1. & Experiment & 30 & 0.12 & 0.16 & Ho accepted & Normally distributed \\
2. & Control & 25 & 0.13 & 0.17 & Ho accepted & Normally distributed \\
\hline
\end{tabular}

The initial data analysis which was then carried out was to test the pretest data homogeneity using the Bartlett test formula. Based on homogeneity test data pretest of $4^{\text {th }}$ grade of SDN 1 Sokawera and $4^{\text {th }}$ grade SDN 3 Sokaw era obtained $\chi^{2}$ score 2.93, with a real level $\alpha=0.05$, from the list of chi-square distributions with $\mathrm{dk}=1$, obtained $\chi_{0,95(1)}^{2}=3.84$. It turns out that $\chi_{\text {score }}^{2}$ are smaller than $\chi_{\text {tables }}^{2}(2.93<3.84)$. So that the hypothesis Ho : $\sigma_{\mathrm{E}}^{2}=\sigma_{\mathrm{K}}{ }^{2}$ is accepted in the real level of 0.05 , and it can be concluded that the value of the pretest of the experimental class and the control class is homogeneous, which means it has the same variation or diversity of values.

The results of the pretest, it can be assumed that when viewed from learning outcomes, students' initial abilities, especially in the cognitive aspects between the experimental class and the control class are the same. In addition, this study was conducted not only to pay attention to the homogeneity of students' cognitive abilities, but also supported by homogeneity in environmental aspects, subject matter and curriculum used, this was done with the aim that the results of the experiments carried out get accurate results.

After conducting preliminary data analysis, researchers conducted experimental activities on mathematics learning, folding symmetry material and flat wake mirroring using the 7 in 1 box and applying the learning model LT and SFaE. LT is a part of cooperative learning that has never been used by teachers in mathematics learning, so this LT is applied to learning in the experimental class. Whereas SFaE is a learning model commonly used by teachers in mathematics learning, so SFaE is applied to learning in the control class.

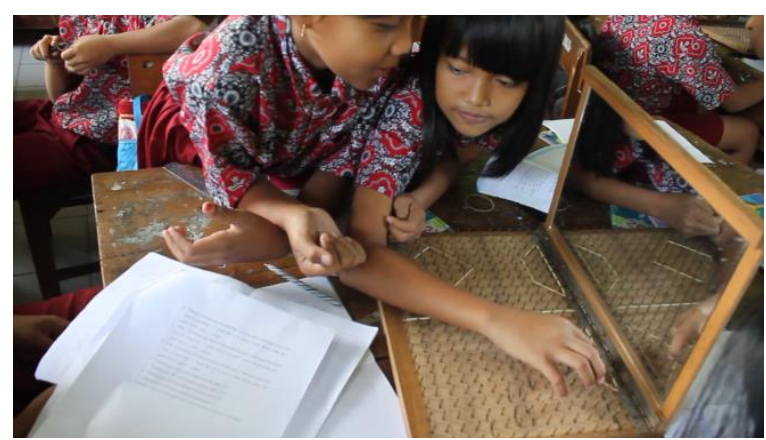

Figure 1. Learning together model assisted with 7 in 1 boxes in mathematics learning 
Each class, both experimental and control classes received treatment 6 times and used a 7 in 1 box. After getting treatment 6 times, posttest was held. The following data are the results of the experimental class posttest and control class,

Table 3. Posttest of Experiment Class (KE) and Control Class (KK)

\begin{tabular}{llcc}
\hline No. & \multicolumn{1}{c}{ Description } & Experiment Class & Control Class \\
\hline 1. & Number of samples & 30 & 25 \\
2. & Minimum score & 70 & 70 \\
3. & Maximum score & 95 & 90 \\
4. & Average & 83 & 77 \\
5. & Complete & 30 & 25 \\
6. & Not complete & - & - \\
\hline
\end{tabular}

the posttest data provides an overview of students' final abilities after obtaining treatment and subject matter. After getting 6 treatments, the posttest score showed satisfactory results, because all students in the experimental class and the control class had reached the KKM score.

The posttest data was then analyzed to test its normality and homogeneity. The following are the results of the normality test for the posttest value in the control and experimental clas ses,

Table 4. Results of Posttest Normality for Experimental Class and Control Class

\begin{tabular}{llccccc}
\hline No. & Class & $\mathrm{n}$ & Lo & Lt (real level 5\%) & Intepretaion & Note \\
\hline 1. & Experiment & 30 & 0.13 & 0.16 & Ho is accepted & Normaly distributed \\
2. & Control & 25 & 0.14 & 0.17 & Ho is accepted & Normaly distributed \\
\hline
\end{tabular}

The homogeneity test of posttest data between class IV SDN 1 Sokawera and class IV SDN 3 Sokawera shows that $\chi^{2}$ score is 0.50 , with a real level $\alpha=0.05$, from the list of chi-square distributions with $\mathrm{dk}$

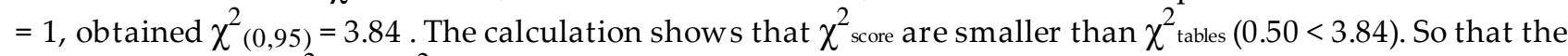
hypothesis Ho: $\sigma_{\mathrm{E}}^{2}=\sigma_{\mathrm{K}}{ }^{2}$ is accepted in the real level of 0.05 , and it can be concluded that the value of the posttest of the experimental class and the control class is homogeneous, which means having the same variation or diversity of values.

The normality and homogeneity test is a prerequisite test before conducting the research hy pothesis test. In this study there are three hypotheses proposed. So that in this study there are three hy pothesis tests. First, test the hypothesis of learning completeness studies in a classical way, this hypothesis test is carried out by using a proportion test of one party. In the experimental class show s that, $\mathrm{Z}$ score (3.16) $>$ Ztable (1.64), Zscore is greater than $z$ tabel then $H o$ is rejected. The results of the hypothesis test can be interpreted that the percentage of classical completeness of students' cognitive cognitive learning outcomes by applying the LT is greater than $75 \%$.

While the results of calculations in the control class show that, $\mathrm{Z}$ score (2.89) > Ztable (1.64), Zscore is greater than $z$ tabel then Ho is rejected. The results of the hypothesis test can be interpreted that the percentage of classical completeness of students' cognitive learning outcomes by applying SFaE is greater than $75 \%$.

Referring to the results of the learning completeness hypothesis test in the experimental class and the control class, it was show $n$ that mathematics learning was successful, because by implementing LT and $\mathrm{SFaE}$ accompanied by the use of 7 in 1 boxes of mathematics learning outcomes students could achieve the completeness of individual learning and classical learning completeness. This is in accordance with the opinion of Djamarah (2010: 108), that learning is successful if $75 \%$ or more of the number of students who take part in the teaching and learning process can achieve a minimum level of success or reach the established KKM.

LT succeeded in achieving classical learning completeness because the implementation of the learning process carried out $\mathrm{w}$ as in accordance with the learning syntax of each learning model listed in the lesson plan. While the success of SFaE in achieving classi fi cation completeness occurred because previously the teachers were accustomed to applying SFaE in mathematics learning. The success of the two models is inseparable because students are given the opportunity to manipulate the 7 in 1 box. This is in line with the results of research (Kontaş, 2016) which states that the use of manipulative objects in mathematics learning is useful for concretizing abstract concepts, so students. In addition, the results of the study (Laski, Jor, Daoust, 
\& Murray, 2015) also showed that using manipulative objects students' abilities in problem solving, critical thinking, and mathematics learning outcomes increased.

When viewed from the average completeness indivual, learning outcomes in the experimental cla ss get higher learning outcomes than the learning outcomes in the control class. This happens because the teacher can motivate students to depend on each other positively, each group shows an interaction, has goals, structure, and groupness. Then in the group discussion activities it was seen that each student interacted with each other when using the 7 in 1 box, it was seen that there was cooperation when completing the LKS, each group seemed to try to be the best group, each student showed that they always played an active role in completing the task given with full responsibility. This is in accordance with Slavin's opinion (2015: 250) that in LT learning emphasizes four elements, namely, face-to-face interaction, positive interdependency, individual responsibility, and interpersonal and small group abilities. So that it can be synthesized that the results of learning mathematics can achieve mastery learning, if in teaching and learning activities in the classroom must emphasize the existence of social interaction and manipulate concrete objects. Students are given the opportunity to interact multi-w ay through group activities and are given a task to be completed together. Through these activities, an active, fun class will be created, besides that each student will feel that he has a role and responsibility to complete a given task, so that students will be encouraged to always learn.

Second, the research hypothesis test increases the learning outcomes of the pretest and posttest using gain and N-gain. Student learning outcomes through LT and SFaE show an increase. The indicator used to determine the increase in the dependent variable (cognitive learning outcomes), refers to the $\mathrm{N}$-gain score $\langle\mathrm{g}\rangle$, with the criteria of increasing height (0.71-1.00), moderate increase (0.3 -0.70), a low increase (0.00.30) (Hake, 1998). The following table shows the improvement in student learning outcomes,

Table 5. Results of Experimental and Control Class Gain Test

\begin{tabular}{ccccccc}
\hline No. & Class & $\mathrm{n}$ & $\bar{x}$ pretest & $\bar{x}$ posttest & $\bar{x}_{g}$ & Criteria gain \\
\hline 1. & Experiment & 30 & 61 & 83 & 22 & moderate increase \\
2. & Control & 25 & 64 & 79 & 15 & moderate increase \\
\hline
\end{tabular}

Table 6. Results of Experimental and Control Class N-Gain Test

\begin{tabular}{ccccccc}
\hline No. & Class & $\mathrm{n}$ & $\bar{x}$ pretest & $\bar{x}$ posttest & $\bar{x}_{N-\text { gain }}$ & Criteria N-gain \\
\hline 1. & Experiment & 30 & 61 & 83 & 0.58 & moderate increase \\
2. & Control & 25 & 64 & 79 & 0.40 & moderate increase \\
\hline
\end{tabular}

Based on the table, it shows that learning outcomes by applying LT and SFaE are both increasing. The increase in student learning outcomes in the experimental class is by applying higher LT. This is in line with research (Hobri, et al., 2018), which shows that group activities contained in the LT can improve students' mathematics learning achievement. With group activities in mathematics learning students feel happy when learning, because they can work together to learn from each other.

In addition, (Gokkurt, Dundar, Soylu, \& Akgun, 2012) through the results of his research also stated that interactions that occur when group formation in mathematics learning using the learning model LT can improve students' mathematics learning achievement. (Capp, Benbenishty, Astor, \& Pineda, 2018) states that student learning outcomes through LT learning can achieve the expected results even though the academic increase is relatively low, but an increase in the social aspects of students can increase significantly.

Based on these three opinions, it can be synthesized that the LT learning model prioritizes joint learning activities through group activities, through which positive interactions will emerge in the classroom, so students can share, help, motivate, facilitate learning with each other, and in the end it affects the student learning outcomes that continue to increase.

Third, the research hypothesis test regarding the effectiveness of learning is done using the $t$-test, the hypothesis tested is that mathematics learning using LT is more effective when compared to learning mathematics by using SFaE when viewed from the results of learning mathematics. The data used to test this hypothesis is the posttest data that has tested the normality of the data and shows that the data is normally distributed so that it does not need to be tested again. Furthermore, the homogeneity test of variance was carried out on the variance of pairs between the experimental and control groups. The test used is the F-test with criteria for homogeneous data if $\mathrm{F}_{\text {score }}>\mathrm{F}_{\text {table. }}$ Based on the results of homogeneity test calculations 
obtained, $F_{\text {score }}(13.25)>F_{\text {table }}(1.95)$ with a significance level of $5 \%$. Thus the variance between the experimental class and the control class is not homogeneous. After it is known that the data are normally distributed, the variance is not homogeneous and the number of samples in the experimental group is not the same as the control group, so according to the predetermined guidelines $t$-test is used with the formula Separated variance, with Ho criteria rejected if $t_{\text {score }}>t t_{\text {score }}$ and Ho accept if $t_{\text {score }}<t$ table.

The results of the posttest $\mathrm{t}$-test showed the results of the calculation of the increase in learning outcomes tscore $(4.41)>t$ table $(1.71)$, while the results of the calculation of normalized learning outcomes $(\mathrm{N}$ Gain) show $t_{\text {score }}(5.16)>t_{\text {table }}(1.71)$, so testing the hypothesis of learning effectiveness rejects Ho, which means that LT is more effective than SFaE in mathematics learning.

\section{RESULT, DISCUSSION, AND SUGGESTIONS}

Learning mathematics using the LT model along with the use of 7 in 1 box can show more effective results because when viewed from the aspect of awarding given by the teacher to students, the LT is superior, scoring is based on individual performance and the success of the group, but individuals and groups do not compete with others (there is no competition between groups). The form of rewards given to groups are based on individual learning of all group members, so as to improve student achievement and have a positive influence on the results released.

Besides that the group on the LT is not merely a group of people. Within the group there are interactions, goals, structure and groupness. Interaction is mutual influence on one individual with another individual. Interactions can take place physically, non-verbally, emotionally and so on. Goals in groups can be both intricate and extrinsic. Intellectual purpose is a goal based on the reason that feeling groups are happy. Extrinsic goals are goals based on the reason that to achieve something cannot be achieved alone, but must be done together. The group structure shows that there is a role in the group. The success of each member in carrying out his role supports the achievement of goals. Groupness indicates that a group is a unit. So it's not just a group of people who are close together. The statement of (Gillies \& Gillies, 2016) shows that group collaboration can create a positive dependence among group members, facilitate promotive interaction, encourage individual accountability, practice social skills, and encourage students to be responsible for the tasks, so students will be motivated to work with each other in achieving goals. (Slavin, 2016) Motivation that arises from group collaboration will encourage students to engage in cognitive elaboration activities, so that students' cognitive abilities can increase. Another fact or that supports the success of LT in mathematics learning is the existence of awards based on scoring based on individual performance and the success of the group, but each individual and groups do not compete with each other (there is no competition betw een groups), with the system aw ards and scoring students will appreciate the success of the group, that is by encouraging and helping each other to achieve success (Slavin, 2016). The effectiveness of LT in mathematics learning is reinforced by the statement Unamba (2015), namely that mathematics learning achievement using learning LT is more effective than traditional learning models in mathematics learning. This is reinforced by the opinion (Thurston, 2013) which states that the application of LT in mathematics learning can improve students' fluency in understanding mathematical concepts, improve problem solving skills and improve mathematical reasoning. LT provides an opportunity for students to instill the habits, skills and attitudes of students who can support the development of students' mathematical reasoning.

Overall, it can be synthesized that the application of LT in mathematics learning provides opportunities for students to explore their abilities in solving a problem and facilitate students to be able to exchange ideas among other students, so that the knowledge gained by students becomes more and students can find a mathematical concept themselves, not just memorization. With this, it can indirectly improve the achievement of students' cognitive learning outcomes.

Based on the explanation above, it can be concluded as follows, namely that students' cognitive learning outcomes in mathematics learning by implementing LT and SFaE along with the use of 7 in 1 box can achieve individual and classical completeness criteria. In addition, there $w$ as an increase in mathematics learning outcomes before and after being subjected to LT and SFaE. Learning mathematics by applying the LT is more effective than learning mathematics by applying SFaE when viewed from the results of learning mathematics. The success of LT in mathematics learning occurs because it is supported by the ability of 
teachers to carry out learning in accordance with the syntax of the LT. This syntax of LT also facilitates students to get to understand the mathematical concepts that they find directly through group discussion activities. Through these discussion activities students get the opportunity to interact, share information with their friends about the various knowledge they have to solve problems related to mathematics, so that it indirectly affects the achievement of student learning outcomes.

Researchers suggest that the LT and box 7 in 1 can be applied to mathematics learning especially in the matter of flat-building symmetry and reflection of flat wake. Seeing the role of the teacher as a facilitator, so that in mathematics learning the teacher must facilitate students to play an active role in learning activities, which is involving students in small group activities and utilizing concrete manipulative objects so students can understand abstract lesson. Therefore, before conducting learning the teacher can design and develop more creative learning by implementing a learning model.

\section{REFERENCES}

Amin, A., \& Suardiman, S. P. (2016). Perbedaan prestasi belajar matematika sisw a ditinjau dari gaya belajar dan model pembelajaran. Jurnal Prima Edukasia, 4, 12-19.

Capp, G., Benbenishty, R., Astor, R. A., \& Pineda, D. (2018). Learning together: Implementation of a peertutoring intervention targeting academic and social-emotional needs. Children \& Schools, 40(3), 173-184. Retrieved from http://dx.doi.org/10.1093/cs/cdy009

Chandrawati, A. E. (2013). 7 in 1, Alat Peraga dari Sekotak Catur. USAID PRIORITAS: Mengutamakan Pembaharuan, Inovasi, dan Kesempatan bagi Guru, Tenaga Kependidikan, dan Siswa.

Cope, L. (2015). Math manipulatives : Making the abstract tangible.Delta Journal of Education, 5(1), 10-19.

Department for Education and Child Development (2013). Final rmpact report: An evaluation of the expansion of Learning Together under the Smarter Schools National Partnership, Part one. South Australia: Government of South Australia.

Djamarah, S. B. (2010). Guru dan anak didik dalam interaksi edukatif suatu pendekatana teoretis psikologis. Jakarta: Rineka llmu.

Fathurrohman (2015). Model-model pembelajaran movatif. Jogjakarta: AR-RUZZ MEDIA.

Furner, J. M., \& Marinas, Carol A. Geoboards to Geogebra: Moving From The Concrete to The Abstract In Geometry. Electronic Proceedings of the Twenty-third Annual International Conference on Technology in Collegiate MathematicsDenver, Colorado, March 17-20.

Ghaith, G. (2003). Bilingual research journal : The Journal of the National Association for Bilingual Education Effects of the Learning Together Model of Cooperative Learning on English as a Foreign Language Reading Achievement, Academic Self- Esteem, and Feelings of School Alienation, (September), 37-41. https://doi.org/10.1080/15235882.2003.10162603

Gillies, R. M., \& Gillies, R. M. (2016). Cooperative learning : Review of research and practice. International Journal of Primary, Elementary and Early Years Education, 41(3).

Gokkurt, B., Dundar, S., Soylu, Y., \& Akgun, L. (2012). The effects of learning together technique which is based on cooperative learning on student achieevement in mathematics class. Procedia - Social and Behavioral Sciences 46,3431-3434.https://doi.org/10.1016/j.sbspro.2012.06.079

Gürbüz, F. (2013). Effects of reading-writing-application and learning together techniques on 6 th grade students ' academic achievements on the subject of " Matter and Temperature. Mije 3(2), 139-150.DOI: 10.13054/mije.13.45.3.2.

Hake, R. R. (1998). Interactive-engagement versus traditional methods: A six-thousand-student survey of mechanics test data for introductory physics courses. American Journal of Physics, 66(1), 64-74.

Hobri, et al. (2018). The implementation of learning together in improving students' mathematical performance. International Journal of Instruction, 11(2), 483-496.

Huda, M. (2013). Model Pengajaran dan Pembelajaran. Yogyakarta : Pustaka Pelajar. 
Johnson, D. W., \& Johnson, R. T. (2006). Learning together and alone : Overview and meta - analysis learning together and alone: Overview and meta-analysis. Journal Asia Pacific Journal of Education. (May), 37-41. https://doi.org/10.1080/0218879020220110.

Johnson, R. B. \& Christensen, L. (2014). Educational research: Quantitative, Qualitative, And Mixed Approaches $5^{\text {th }}$ Edition. United States of Amerika: SAGE Publications, Inc.

Joyce, B. \& Weil, M. (2015). Models of teaching, ninth edition. Boston: Pearson.

Kontaş, H. (2016). The effect of manipulatives on mathematics achievement and attitudes of secondary school students. Journal of Education and Learning, 5(3), 10-20. https://doi.org/10.5539/jel.v5n3p10

Kristiani, N., \& Prasetyo, Z. K. (2016). Keefektıfan Pembelajaran Metematıka Melaluı Penggunaan Medıa Benda Konkret Pada Kelas V Sd Timuran. Jurnal Prima Edukasia, 4, 163-175.

Laski, E. V, Jor, J. R., Daoust, C., \& Murray, A. K. (2015). What makes mathematics manipulatives effective? Lessons from cognitive science and montessori education. Lessons From Cognitive Science and Montessori Education, https://doi.org/10.1177/2158244015589588

Meganingtyas, B. R., Winarni, R., \& Murwaningsih, T. (2019). The effect of using course review horay and talking stick learning methods tow ards social science learning result review ed from learning interest. International Journal of Educational Research Review, 4(2), 70-77.

Muchyidin, \& Kartika, I. (2014). Perbandingan Pemahaman Matematika Siswa Antara Kelas yang Menggunakan Metode Student Facilitator And Explaining dengan Metode Peer Teaching Pokok Bahasan Bangun Ruang Sisi Datar, 3(2).

Mulyanto, H., \& Indriayu, M. (2018). The effect of problem based learning model on student mathematics learning outcomes viewed from critical thinking skills. International Journal of Educational Research Review, 3(2), 37-45.

Özsoy, N. \& Yildiz, N. (2004). The effect of learning together technique of cooperative learning method on student achievement in mathematics teaching 7 th class of primary school. The Turkish Online Journal of Educational Technology - TOJET, 3(3), Article 7. 49-54.

Rahayu, S., Windayana, H., \& Halimah, L. (2015). Model Kooperatif Tipe Learning Together untuk Meningkatkan Kemampuan Komunikasi Matematis Siswa Sekolah Dasar. Jurnal PGSD Kampus Cibiru, $3(2)$.

Rahmaw ati, R. D., \& Mahmudi, A. (2014). Jurnal Prima Edukasia, Volume 2 - Nomor 1, 2014, 2(1), 102-115.

Republik Indonesia. (2006). Peraturan Menteri Pendidikan Nasional RI Nomor 22 Tahun 2006 tentang Standar Isi untuk Satuan Pendidikan Dasar dan Menengah. Jakarta: Menteri Pendidikan Nasional.

Salahudeen, A. B., \& Saidu, S. (2016). Effects of geoboard and geographical globe on seniior secondary school students ' performance in mathematics in kaduna state. ATBU, Journal of Science, Technology \& Education (JOSTE),. 4 (1)140-148.

Scandrett, H. (2008). Using geoboards in primary mathematics. Australian Primary Mathematics Classroom, $13(2), 29-32$.

Slavin, R. E . (2015). Cooperative learning : Teori, Riset dan Praktik. Edisi 15. (Terjemahan N. Yusron, Bandung: Nusa Media). Boston: Allyn and Bacon.

Thurston, A. (2013). Learning together in mathematics. Centre for Effective Education, Queen's University Belfast.

Unamba, E.C. (2015). Effect of learningtogether technique on pupils achievement in primary mathematics. Jurnal Research in Education and Society. 6(1), 59-65.

Warner, S., \& Kaur, A. (2017). The Perceptions of Teachers and Students on a 21 st Century Mathematics Instructional Model. International Electronic Journal Of Mathematics Education, 12(2), 193-215. 